ANDRZEJ DAKOWICZ ${ }^{3}$

Zakład Psychologii Społecznej i Rozwoju Człowieka

Wydział Pedagogiki i Psychologii

Uniwersytet w Bialymstoku

\title{
POTRZEBY INDYWIDUALNE MAŁŻONKÓW O WYSOKIM I NISKIM POZIOMIE TRANSGRESJI
}

\section{STRESZCZENIE}

Jednym z istotnych elementów sieciowej teorii osobowości Kozieleckiego jest psychon motywacyjny, którego dynamika w największym stopniu zależy od siły potrzeb psychicznych. Celem badań prezentowanych w artykule było określenie poziomu potrzeb indywidualnych: witalnych, poznawczych, społecznych i osobistych małżonków charakteryzujących się wysokim i niskim poziomem transgresji. Zbadano 100 par małżeńskich, wykorzystując Skalę transgresji i Test indywidualnych potrzeb. Wyodrębniono z nich po 30 małżonków o wysokim poziomie transgresji i 30 małżonków o niskim poziomie transgresji. Między żonami o wysokim i niskim poziomie transgresji nie zarejestrowano różnic istotnych statystycznie odnośnie do siły natężenia potrzeb psychicznych. Mężowie o wysokim poziomie transgresji charakteryzują się zdecydowanie silniejszymi potrzebami poznawczymi niż mężowie o niskim poziomie transgresji, mężowie natomiast o niskim poziomie transgresji charakteryzują się zdecydowanie silniejszymi potrzebami osobistymi niż mężowie o wysokim poziomie transgresji.

Słowa kluczowe: sieciowa teoria osobowości, psychon motywacyjny, transgresja, potrzeby indywidualne (witalne, poznawcze, społeczne, osobiste)

\section{INDIVIDUAL NEEDS OF SPOUSES WITH HIGH AND LOW LEVELS OF TRANSGRESSION}

\begin{abstract}
One of the key elements of the Kozielecki's theory of personality network is the motivation psychon. Its dynamics to the greatest extent depends on the strength of psychological needs. The aim of the research presented in the article was to determine the level of individual needs: vital, cognitive, social and personal, spouses with high and low levels of transgression. 100 couples were examined using the Scale of Transgression and the Test of Individual Needs. 30 spouses of high-level transgression and 30 spouses of low-level transgression were examined.

There were no statistically significant differences in the intensity of the needs of mental strength between the wives with high and low level of transgression. Husbands with a high levels of transgression are characterized by much stronger cognitive needs than men with a low level of transgression,
\end{abstract}

\footnotetext{
${ }^{3}$ Adres do korespondencji: a.dakowicz@uwb.edu.pl
} 
while men with a low level of transgression have a much stronger personal needs, than the men with a high level of transgression.

Keywords: network theory of personality, motivation psychon, transgression, individual needs (vital, cognitive, social, personal)

\section{WPROWADZENIE TEORETYCZNE}

Pięć wieków przed Chrystusem chiński filozof Konfucjusz zauważył, że kiedy w małżeństwie panuje miłość, w rodzinie pojawia się zadowolenie prowadzące do wzrostu dobrobytu w narodzie, który ostatecznie wpływa na pokój w świecie (Prasad, 2006). Można powiedzieć, że u podłoża stabilizacji ogólnoświatowej i pokoju na świecie leży jakość związków małżeńskich tworzonych przez ludzi różnych narodowości. Wielorakie trudności związane z funkcjonowaniem związków małżeńskich (Gottman, 2014), będące w dużej mierze wynikiem konsumpcyjnego stylu życia (Łukowska, 2011), sprawiają, że niestety w wielu przypadkach kończą się one rozwodem lub separacją (Kowerski, Kowal, 2014).

Siłę i znaczenie instytucji małżeństwa jako trwałego związku kobiety i mężczyzny, który to związek po narodzinach dziecka przekształca się w rodzinę, osłabiają coraz częściej propagowane formy alternatywne, takie jak: 1) DINK - od angielskich słów dual income - no kids, tzn. podwójny dochód - żadnych dzieci. Małżonkowie wykluczają podjęcie funkcji rodzicielskich na rzecz realizacji osobistych planów (Biernat, Sobierajski, 2007); 2) LAT - od angielskich słów living apart together, tzn. żyjąc oddzielnie razem, partnerzy są ze sobą, ale nie prowadzą wspólnego gospodarstwa domowego (Biernat, Sobierajski, 2007); 3) kohabitacja - z łacińskiego habitare - 'mieszkać' i com - 'wespół, z', tzn. współzamieszkiwanie partnerów bez ślubu (Jabłoński, Ostasz, 2001). Nierzadko kohabitacja jest traktowana jako preludium, sprawdzenie się i upewnienie, że trafiło się na odpowiedniego kandydata, zanim zostanie zawarty formalny związek małżeński (Gizicka, 2008). Okazuje się, że jakość związków małżeńskich poprzedzonych kohabitacją jest niższa od związków małżeńskich, które nie były poprzedzone wspólnym zamieszkaniem (Janicka, 2010).

Pomimo narastającego zjawiska rozpadu związków małżeńskich oraz nieustannych zmian zachodzących w zakresie kształtu życia małżeńskiego badania prowadzone wśród młodych Polaków wskazują, że większość z nich planuje w bliższej lub dalszej przyszłości zawrzeć związek małżeński, którego powodzenie, wraz z posiadaniem dzieci, stanowi najważniejszy cel ich życia (Plopa, 2010). Podobnie wyniki szerszych badań przeprowadzonych wśród młodzieży pięciu krajów o zróżnicowanej kulturze, religijności i odmiennym poziomie rozwoju gospodarczego: w Niemczech, Hiszpanii, Korei Południowej, na Litwie i w Polsce wskazują, że wśród najważniejszych planów życiowych pierwsze miejsce zajmuje rodzina i związane z nią wartości (Dyczewski, 2007).

Współczesne przemiany w rozumieniu związku małżeńskiego (Rostowski, 2009), jak również rysująca się perspektywa wchodzenia w związki małżeńskie kolejnego pokolenia kobiet i mężczyzn stawiają przed nauką ważne zadania, które na gruncie różnych teorii zmierzają do poznawania aktualnych czynników i mechanizmów kształtujących satysfakcjonującą relację małżeńską (Rostowski, Rostowska, 2014). Jednym z nich jest np. określenie warunków, które powinny być spełnione, aby umożliwić małżonkom efektywne godzenie odgrywanych przez nich ról rodzinnych i zawodowych (Lachowska, 2012). Wiedza ta ma 
być przydatna w takim kreowaniu rzeczywistości życia małżeńskiego, aby zwiększać jego jakość i dawać małżonkom poczucie satysfakcji z osobistego spełniania się w małżeństwie.

Prezentowane wyniki przeprowadzonych badań są próbą określenia zależności między poziomem transgresji małżonków a ich potrzebami indywidualnymi w świetle nowego rozumienia ludzkiej psychiki, jakim jest psychotransgresjonizm (Kozielecki, 2007). Idea transgresji z powodzeniem wykorzystywana jest m.in. do budowania modeli zdolności i uzdolnień (Popek, Bernacka, 2008), opisu zjawisk afektywnych (Gorbatkow, 2008), lepszego rozumienia mechanizmów uzależnień i podstaw skutecznej terapii (Ślaski, 2013), badania skłonności do ryzyka (Studenski, 2006), analizy procesów reform gospodarczych (Kozielecki, 2006), wyjaśniania mechanizmów działań przedsiębiorczych (Kwarciak, 2003) i sukcesów menedżerskich (Strzałecki, 2006) czy też zjawiska globalizacji (Ledzińska, 2006). Psychotransgresjonizm odwołuje się do pojęcia granic i ich przekraczania, zachowań ochronnych i transgresyjnych, a także sieciowej teorii osobowości (Kozielecki, 2007), proponując nowe spojrzenie na relacje małżeńskie, mogące mieć charakter konstruktywnych lub destruktywnych transgresji małżeńskich. W miarę umacniania wzajemnej miłości małżonkowie coraz bardziej uwalniają się od minionych doświadczeń, przekraczają granice, które ich wcześniej zniewalały, m.in. egocentryzmu, dawnych ran i narzuconych sobie ograniczeń. Osiągają większe poczucie panowania nad sobą i większą odpowiedzialność za własne czyny (Dakowicz, 2014). Poszerzającej się odpowiedzialności towarzyszy silniejsza miłość, i cały cykl, wchodząc na wyższy poziom, zmierza ku pełniejszemu rozwojowi. Wraz ze wzrostem wzajemnej miłości umacnia się wolność, co w konsekwencji zwiększa poczucie odpowiedzialności i wpływa na wzrost miłości. Wolność, odpowiedzialność i miłość stanowią trójkąt granic, których przestrzeganie prowadzi do wzrostu satysfakcji w związku małżeńskim (Cloud, Townsend, 2007). Zachowania ochronne umożliwiają małżonkom funkcjonowanie na co dzień, niezbędne do przystosowania się, ukształtowania i utrzymania najbliższego środowiska zaspokajającego podstawowe potrzeby. Pozwalają osiągnąć zdrowie fizyczne i psychiczne, wzmacniają wiarę we własne siły. Zachowania transgresyjne związane są m.in. z ekspansją, twórczością, dążeniem do rozwoju indywidualnego „być” i „mieć” (Fromm, 1999; Kozielecki, 2007). Prowadzą ku kształtowaniu ludzkiej osobowości rozumianej jako sieciowa struktura pięciu równoważnych psychonów.

Psychon poznawczy zapewnia orientację w świecie, pozwala zrozumieć złożone relacje z innymi przez posiadaną i ciągle zdobywaną wiedzę o sobie i innych. Psychon instrumentalny zawiera zbiór umiejętności i sprawności, dzięki którym człowiek ciągle nabywa nowe sposoby działania w ciągu życia, adekwatne do zmieniających się warunków. Psychon motywacyjny rozpoczyna proces motywacyjny, określa jego kierunek, podtrzymuje go lub przerywa dalszą aktywność. Dynamika procesu motywacyjnego w największym stopniu uzależniona jest od potrzeb psychicznych. Psychon emocjonalny składa się z trwałych układów neurofizjologicznych i psychicznych generujących stany i procesy emocjonalne oraz afekty i nastroje, którym towarzyszą zmiany somatyczne i różnorodność zachowań. Psychon osobisty stanowi głęboką strukturę neurofizjologiczną, psychiczną i duchową, w której znajdują się treści egzystencjalno-tożsamościowe, dotyczące danej osoby ludzkiej (Kozielecki, 2007).

Im częściej małżonkowie podejmują działania transgresyjne, tym więcej mają okazji, aby poznać siebie i współmałżonka. Klimat tworzonego związku jest efektem specyficznej formy transgresji podejmowanej w rzeczywistości życia małżeńskiego przez oboje 
małżonków, polegającej na rozpoznawaniu pojawiających się trudności, poszukiwaniu ich przyczyn i podejmowaniu wspólnych działań zmierzających do ich przezwyciężenia (Dakowicz, 2012). Dynamika połączeń wewnątrz psychonów i między psychonami $\mathrm{w}$ trakcie podejmowania zachowań transgresyjnych uzależniona jest od potencjalnej mocy poszczególnych psychonów. Można założyć, że im większa jest potencjalna moc poszczególnych psychonów, tym większe jest prawdopodobieństwo tworzenia i funkcjonowania sprawnej sieci umożliwiającej pełniejszy rozwój osobowości, co pozwala podejmować skuteczniejsze działania transgresyjne, prowadzące w konsekwencji do wzrostu satysfakcji obojga małżonków z tworzonego związku. Ponieważ idea psychotransgresjonizmu jest nowa i nie opracowano jeszcze odpowiednich narzędzi pozwalających na operacjonalizację wszystkich psychonów oraz uchwycenie dynamiki powiązań wewnątrz nich i pomiędzy nimi, w prezentowanym opracowaniu skupiono się na operacjonalizacji jednego z pięciu psychonów - motywacyjnego - z nadzieją, że metodą kolejnych przybliżeń stanie się to możliwe w przyszłości.

\section{PSYCHON MOTYWACYJNY JAKO ELEMENT SIECIOWEJ STRUKTURY OSOBOWOŚCI}

Osobowość, będąca konstruktorem biografii człowieka, aktywizowana jest przez bodźce i sytuacje zewnętrzne (materialne, poznawcze, społeczne) lub sygnały wewnętrzne (myśli, emocje, potrzeby, sny). Zarówno jeden, jak i drugi rodzaj sygnałów może być uświadamiany lub nieuświadamiany (Kozielecki, 2007). Odpowiadając na docierające sygnały, człowiek jest skłonny podejmować określone działania, wydatkując większy lub mniejszy wysiłek w określonym czasie (Alderfer, 1992). Stara się dążyć nieustannie do wielostronnego rozwoju osobowości, przesuwając granice własnych osiągnięć, aby ostatecznie wzbogacać siebie i swoje otoczenie. W pewnym sensie człowiek dąży do potwierdzenia i wzrostu własnej wartości (Kozielecki, 2007), czemu towarzyszy duma i satysfakcja z uzyskanych osiągnięć, mająca również aspekt narcystyczny (Tokarz, 2005). Analiza przeprowadzonych do tej pory badań wskazuje na szczególne znaczenie w podejmowaniu działań transgresyjnych takich predyspozycji, jak: aprobata życia, silne ego, samorealizacja, giętkość struktur poznawczych i wewnętrzna sterowność (Strzałecki, 2006). Generalnie kobiety charakteryzują się w znacznym stopniu transgresją w sferze etycznej i rodzinnej, mężczyźni natomiast w sferze zawodowej i materialnej (Ślaski, 2012).

Dynamika procesu motywacyjnego w największym stopniu uzależniona jest od potrzeb, które są formułowane różnie, w zależności od ujęć teoretycznych. Karen Horney (1993) za najważniejszą w kontekście motywacyjnym uważała potrzebę bezpieczeństwa i potrzebotwórczy konflikt pomiędzy „ja realnym” oraz „ja idealnym”. Abraham Maslow (1990) opracował układ potrzeb, które przez hierarchiczny porządek od potrzeb fizjologicznych przez potrzeby bezpieczeństwa, przynależności i miłości, szacunku, samourzeczywistnienia prowadzą człowieka do pełnego rozwoju. Kazimierz Obuchowski (1995) dynamizację zachowań ludzkich upatruje w potrzebach fizjologicznych, seksualnych, poznawczych, kontaktu emocjonalnego i sensu życia. Najbardziej rozbudowaną strukturę ludzkich potrzeb prezentuje Murray: 1) potrzeby pierwotne (wiscerogeniczne) i wtórne (psychogeniczne); 2) potrzeby zewnętrzne i utajone; 3) potrzeby skoncentrowane i rozproszone; 4) potrzeby proaktywne i reaktywne; 5) potrzeby aktywności, formy i skoncentrowane na wyniku (Hall, Lindzey, 1990). Józef Kozielecki (2007), odnosząc się do czterech światów, 
w których człowiek funkcjonuje, wyróżnia cztery rodzaje potrzeb: 1) witalne - związane z przekazem genetycznym, zaspokajane w świecie materialnym. Umożliwiają one utrzymanie życia jednostki i gatunku: pokarmowe, fizjologiczne, seksualne, zdrowotne, bezpieczeństwa fizycznego; 2) poznawcze - zaspokajane w sferze nauki, filozofii, literatury, muzyki, malarstwa, informatyki. Należą do nich m.in. potrzeby: kompetencji, informacji, eksploracji, estetyki; 3) społeczne - zaspokajane w kontaktach interpersonalnych. Należą do nich m.in. potrzeby: bezpieczeństwa społecznego, afiliacji, miłości, braterstwa, dominacji nad innymi, władzy; 4) osobiste - związane ze światem wewnętrznym jednostki. Należą do nich m.in. potrzeby: indywidualnych osiągnięć, własnej wartości, sensu życia, intymności, transcendencji.

Celem podjętych badań jest próba określenia siły natężenia potrzeb psychicznych, będących elementem dynamizującym psychon motywacyjny, małżonków o wysokim i niskim poziomie transgresji. Przypuszcza się, że wyższemu poziomowi transgresji małżonków będzie towarzyszyło większe natężenie potrzeb psychicznych, co zwiększa siłę psychonu motywacyjnego. Wykorzystując praktyczną i syntetyczną klasyfikację potrzeb odnoszących się do czterech światów, w których człowiek funkcjonuje: witalne, poznawcze, społeczne i osobiste (Kozielecki, 2007), sformułowano następującą hipotezę badawczą: małżonkowie o wysokim poziomie transgresji charakteryzują się silniejszymi potrzebami witalnymi, poznawczymi, społecznymi i osobistymi niż małżonkowie o niskim poziomie transgresji.

\section{METODA}

\section{CHARAKTERYSTYKA BADANYCH I PRZEBIEG BADAŃ}

Badaniami objęto 100 par, pozostających w pierwszych formalnych związkach małżeńskich z minimum 5-letnim stażem, złożonych z osób do 45. roku życia, mających wykształcenie średnie lub wyższe, aktywnych zawodowo i pełniących funkcje rodzicielskie. Były to pary małżeńskie mieszkające w Białymstoku lub najbliższych okolicach. Przyjęcie powyższych kryteriów zmierzało ku jak największemu ujednoliceniu grupy badanych, aby zminimalizować modyfikujący wpływ na siłę natężenia potrzeb psychicznych innych zmiennych niż kontrolowana zmienna niezależna - poziom transgresji. Jeżeli para małżeńska spełniała wszystkie przyjęte kryteria, zapraszano ją na Wydział Pedagogiki i Psychologii Uniwersytetu w Białymstoku lub przeprowadzano badanie w mieszkaniu małżonków, uzgodniwszy dogodny termin. Na podstawie wyników Skali transgresji (Studenski, 2006) wyodrębniono grupę 30 małżonków, którzy uzyskali wyniki najwyższe - żony o wysokim poziomie transgresji i mężów o wysokim poziomie transgresji oraz grupę 30 małżonków, którzy uzyskali wyniki najniższe - żony o niskim poziomie transgresji i mężów o niskim poziomie transgresji. Pominięto w analizie małżonków, którzy uzyskali przeciętne wyniki w zakresie poziomu transgresji. Szczegółowe dane dotyczące charakterystyki badanych małżonków o wysokim i niskim poziomie transgresji zawiera tabela 1. 
Tabela 1

Charakterystyka badanych matżonków

\begin{tabular}{lccccc}
\hline & & \multicolumn{4}{c}{ Typy badanych małżonków } \\
Wybrane cechy & & $\begin{array}{l}\text { Żony } \\
\text { o wysokim } \\
\text { poziomie } \\
\text { transgresji } \\
(N=30)\end{array}$ & $\begin{array}{l}\text { Męzowie } \\
\text { o wysokim } \\
\text { poziomie } \\
\text { transgresji } \\
(N=30)\end{array}$ & $\begin{array}{l}\text { Żony } \\
\text { o niskim } \\
\text { poziomie } \\
\text { transgresji } \\
(N=30)\end{array}$ & $\begin{array}{l}\text { Mężowie } \\
\text { o niskim } \\
\text { poziomie } \\
\text { transgresji } \\
(N=30)\end{array}$ \\
\hline Poziom transgresji & & 60,2 & 66,2 & 43,8 & 47,6 \\
\hline Wiek & & 34,3 lat & 35,4 lat & 37,6 lat & 39,4 lat \\
\hline \multirow{2}{*}{ Wykształcenie } & Wyższe & $26(86,7 \%)$ & $25(83,3 \%)$ & $19(63,3 \%)$ & $15(50,0 \%)$ \\
& Średnie & $4(13,3 \%)$ & $5(16,7 \%)$ & $11(36,7 \%)$ & $15(50,0 \%)$ \\
\hline Staż małżeński & & 11,8 lat & 11,4 lat & 14,1 lat & 12,9 lat \\
\hline \multirow{2}{*}{$\begin{array}{l}\text { Liczba } \\
\text { dzieci }\end{array}$} & Jedno & $11(36,7 \%)$ & $11(36,7 \%)$ & $9(30,0 \%)$ & $11(36,7 \%)$ \\
& Dwoje & $17(56,7 \%)$ & $14(46,8 \%)$ & $13(43,4 \%)$ & $11(36,7 \%)$ \\
& Troje & $2(6,6 \%)$ & $2(6,6 \%)$ & $6(20,0 \%)$ & $7(23,3 \%)$ \\
& Czworo & 0 & $1(3,3 \%)$ & $1(3,3 \%)$ & $1(3,3 \%)$ \\
& Pięcioro & 0 & $2(6,6 \%)$ & $1(3,3 \%)$ & 0 \\
\hline
\end{tabular}

\section{NARZĘDZIA BADAWCZE}

Poziom transgresji badanych małżonków określono, wykorzystując Skale transgresji opracowaną przez Studenskiego (2006) zgodnie z koncepcją psychotransgresjonizmu Kozieleckiego (2007). Daje ona możliwość ilościowego oszacowania transgresji u badanej osoby za pomocą wymiernie opisanych rezultatów działań transgresyjnych, ich częstotliwości, uczestnictwa w realizacji celów transgresyjnych, względnie satysfakcji przeżywanej w związku z zachowaniami transgresyjnymi. Opracowane wskaźniki psychometryczne i wyodrębnione cztery czynniki - nastawienie na dominowanie nad innymi, innowacyjność wykorzystywana w projektowaniu nowych rozwiązań, motywacja do wzbogacania kompetencji i odwaga w podejmowaniu nowych zadań - pozwalają określić skalę jako dobre narzędzie do pomiaru transgresyjności (Studenski, 2006).

Do pomiaru siły natężenia potrzeb psychicznych skonstruowano Test indywidualnych potrzeb (Dakowicz, 2011) w oparciu o pomysł Reddina (1993). Stworzono 14 grup składających się z 14 konkretnych potrzeb (po jednej z każdej kategorii), co do których znaczenia w życiowych dążeniach badani wyrażali swoją opinię. W każdej z czternastu grup mieli do podziału cztery punkty, które mogli rozdysponować według własnego uznania, zgodnie z tym, czego najbardziej by chcieli, przypisując na przykład jednej potrzebie cztery punkty, dwóm potrzebom po dwa punkty czy każdej z nich po jednym punkcie. Suma punktów przyznanych konkretnym potrzebom z określonej kategorii wskazuje, które z potrzeb: witalne, poznawcze, społeczne czy osobiste są u badanej osoby najsilniejsze. Duża liczba punktów w określonej kategorii potrzeb (maksymalnie 56) wskazuje na ich wysokie natężenie, a niska liczba punktów (minimalnie 0) - na ich niskie natężenie. Przykładowe pozycje testu: 1) potrzeba witalna - Chciałbym lepiej sięodżywiać; 2) potrzeba 
poznawcza - Chciałbym mieć więcej czasu na refleksję; 3) potrzeba społeczna - Chciałbym mieć więcej przyjaciól; 4) potrzeba osobista - Chciałbym, żeby mnie bardziej szanowano.

Opracowując uzyskane wyniki, wykorzystano program komputerowy SPSS 14.0 PL for Windows, za pomocą którego obliczono wartość testu t-Studenta dla porównywanych małżonków o wysokim i niskim poziomie transgresji (Górniak, Wachnicki, 2003).

\section{WYNIKI}

Sformułowana w oparciu o koncepcję psychotransgresjonizmu Kozieleckiego (2007) hipoteza mówiła o tym, że małżonkowie o wysokim poziomie transgresji charakteryzują się silniejszymi potrzebami witalnymi, poznawczymi, społecznymi i osobistymi niż małżonkowie o niskim poziomie transgresji. Analiza wyników przeprowadzonych badań wskazuje na różnicę, jaka wystąpiła w tej kwestii między żonami oraz mężami.

Żony o wysokim poziomie transgresji w największym stopniu preferują potrzeby osobiste, następnie poznawcze, społeczne i na końcu witalne. W przypadku żon o niskim poziomie transgresji w największym stopniu preferowane są również potrzeby osobiste, ale w dalszej kolejności preferują one potrzeby witalne, społeczne i na końcu poznawcze. Porównując siłę natężenia poszczególnych potrzeb indywidualnych między badanymi grupami żon, zauważa się, że nieznacznie silniejsze u żon o wyższym poziomie transgresji są potrzeby poznawcze i społeczne, u żon natomiast o niższym poziomie transgresji - witalne i osobiste. Nie są to jednak różnice osiągające poziom istotności statystycznej.

Tabela 2

Potrzeby indywidualne żon o wysokim i niskim poziomie transgresji

\begin{tabular}{llclcrl}
\hline $\begin{array}{l}\text { Rodzaje } \\
\text { potrzeb }\end{array}$ & \multicolumn{2}{l}{$\begin{array}{l}\text { Żony o wysokim poziomie } \\
\text { transgresji }(N=30)\end{array}$} & \multicolumn{2}{l}{$\begin{array}{l}\text { Źny o niskim poziomie } \\
\text { transgresji }(N=30)\end{array}$} & \multicolumn{2}{l}{ Istotność różnic } \\
& $M$ & $S D$ & $M$ & $S D$ & $t$ & $p<$ \\
\hline Witalne & 11,97 & 6,14 & 13,33 & 5,70 & $-0,89$ & n.i. \\
Poznawcze & 14,57 & 6,52 & 12,93 & 6,99 & 0,94 & n.i. \\
Społeczne & 13,90 & 4,70 & 13,07 & 5,08 & 0,66 & n.i. \\
Osobiste & 15,57 & 6,91 & 16,67 & 7,62 & $-0,59$ & n.i. \\
\hline
\end{tabular}

Mężowie o wysokim poziomie transgresji w największym stopniu preferują potrzeby poznawcze, następnie społeczne, witalne i na końcu osobiste. Mężowie o niskim poziomie transgresji w największym stopniu preferują potrzeby osobiste, następnie społeczne, witalne i na końcu poznawcze. Różnice istotne statystycznie między badanymi grupami mężów zarejestrowano w przypadku dwóch potrzeb. Mężowie o wysokim poziomie transgresji mają silniejsze potrzeby poznawcze $-t(58)=3,33, p<0,001$ niż mężowie o niskim poziomie transgresji. Mężowie o niskim poziomie transgresji mają silniejsze potrzeby osobiste $-t(58)=-2,67, p<0,01$ niż mężowie o wysokim poziomie transgresji. 
Tabela 3

Potrzeby indywidualne mężów o wysokim i niskim poziomie transgresji

\begin{tabular}{lcccccc}
\hline Rodzaje potrzeb & \multicolumn{2}{l}{$\begin{array}{l}\text { Mężowie o wysokim } \\
\text { poziomie transgresji } \\
(N=30)\end{array}$} & $\begin{array}{l}\text { Mężowie o niskim } \\
\text { poziomie transgresji } \\
(N=30)\end{array}$ & Istotność różnic \\
& $M$ & $S D$ & $M$ & $S D$ & $t$ & $p<$ \\
\hline Witalne & 13,37 & 6,19 & 12,90 & 4,25 & 0,34 & n.i. \\
Poznawcze & 16,73 & 6,66 & 11,67 & 4,98 & 3,33 & 0,001 \\
Społeczne & 13,43 & 6,08 & 15,17 & 4,79 & $-1,23$ & n.i. \\
Osobiste & 12,47 & 5,73 & 16,27 & 5,28 & $-2,67$ & 0,01 \\
\hline
\end{tabular}

\section{PODSUMOWANIE I DYSKUSJA WYNIKÓW}

Przyjęta hipoteza, zakładająca silniejsze natężenie potrzeb psychicznych u małżonków o wyższym poziomie transgresji niż u małżonków o niższym poziomie transgresji, potwierdziła się częściowo. Między żonami o wysokim i niskim poziomie transgresji nie ma różnic istotnych statystycznie odnośnie do nasilenia potrzeb witalnych, poznawczych, społecznych i osobistych. Zauważalna jest jednak różnica, jeśli chodzi o układ najsilniejszych i najsłabszych potrzeb w obu grupach badanych kobiet. U żon o wysokim poziomie transgresji dominują potrzeby osobiste, następnie poznawcze, społeczne i na końcu witalne. Podobnie u żon o niskim poziomie transgresji, najsilniejsze są potrzeby osobiste, ale w dalszej kolejności występują witalne, społeczne i na końcu poznawcze. Im silniejsze są określone potrzeby, tym większe jest prawdopodobieństwo uruchomienia procesu motywacyjnego zmierzającego do ich zaspokojenia (Miner, Dowson, Malone, 2013).

W przypadku żon o wysokim poziomie transgresji realizacja potrzeb osobistych łączy się z potrzebą zdobycia wiedzy o świecie zewnętrznym i o sobie samych, co mocno wiąże się z czasowym egocentryzmem (Kozielecki, 2007; Ślaski, 2012), mogącym doprowadzić do psucia się struktury związku małżeńskiego (Tański, 2005). Pojawia się zjawisko przeciwne transgresji, które określane jest jako degresja (Kozielecki, 2007). Jednak pełniejsze zaspokojenie powyższych potrzeb prowadzi w konsekwencji do coraz lepszego kontaktu z otaczającą rzeczywistością i polepszenia jakości dialogu małżeńskiego (Baniak, 2004). Żony o wysokim poziomie transgresji są w stanie częściej zauważyć w relacjach rodzinnych pojawiające się zależności i biorąc je pod uwagę, pozytywnie wpływać na klimat życia rodzinnego. Dostrzegane niuanse i wszelkie nieporozumienia mogą być dla nich wyzwaniem, aby sprawę podjąć i rozwiązać, szczególnie gdy dotyczą one kwestii etycznych (Ślaski, 2012).

U żon o niskim poziomie transgresji siła natężenia potrzeb osobistych bliska jest sile natężenia potrzeb witalnych, co w konsekwencji może prowadzić do nadmiernego skupiania się na sobie samej w dłuższym czasie i obniżenia jakości relacji małżeńskiej (Janicka, 2004). W relacji małżeńskiej podejmowanie działań na własną rękę może się spotkać z oporem ze strony współmałżonka, np. z powodu zwykłego braku zrozumienia. Zaistniały stan napięcia psychicznego prowadzi zwykle do konfliktów (Kornaszewska-Polak, 2013) lub zachowań roszczeniowych (Żemojtel-Piotrowska, Piotrowski, Baran, 2014), co w konsekwencji wpływa negatywnie na klimat życia rodzinnego. Wyniki wcześniej prowadzonych 
badań w ujęciu psychotransgresyjnym wskazują na mniejsze zadowolenie z małżeństwa żon charakteryzujących się niższym natężeniem potrzeb poznawczych (Dakowicz, 2011).

Natężenie i układ potrzeb indywidualnych różnicuje mężów o wysokim i niskim poziomie transgresji. Mężowie o wysokim poziomie transgresji charakteryzują się zdecydowanie silniejszymi potrzebami poznawczymi, następnie społecznymi, witalnymi i na końcu osobistymi. Podobnie jak w przypadku żon o wysokim poziomie transgresji, realizacja potrzeb poznawczo-społecznych mężów o wysokim poziomie transgresji łączy się z czasowym egocentryzmem zagrażającym zdrowemu funkcjonowaniu związku małżeńskiego (Tański, 2005). Występuje zjawisko degresji (Kozielecki, 2007), które jednak ma charakter czasowy. Pełniejsze zaspokojenie powyższych potrzeb prowadzi zwykle do lepszego rozumienia otaczającej rzeczywistości i mechanizmów funkcjonowania świata społecznego. Wpływa to na wzrost poczucia własnej wartości (MacKenzie, Baumeister, 2014) oraz lepsze rozumienie rzeczywistości życia małżeńsko-rodzinnego, a przez podejmowanie adekwatnych działań zwiększa poczucie szczęścia małżeńskiego (Stępniak-Łuczywek, 1997).

U mężów o niskim poziomie transgresji układ potrzeb kształtuje się odwrotnie. Zdecydowanie silniejsze mają oni potrzeby osobiste, następnie społeczne, witalne i na końcu poznawcze. W przypadku mężów o niskim poziomie transgresji należy się spodziewać częstszego pojawiania się procesów motywacyjnych zmierzających do realizacji potrzeb osobistych. Koncentracja na tym, co „moje”, pozostawia w tle to, co „nasze” (Slotter, Duffy, Gardner, 2014). W konsekwencji może dochodzić do większego skupiania się na sobie niż na relacji małżeńskiej czy życiu rodzinnym i - przez zmniejszenie empatii - obniżać poziom zadowolenia z małżeństwa w dłuższym odcinku czasowym (Sitarczyk, Waniewski, 2002; Perrone-McGovern i in., 2014).

Uzyskane wyniki wskazujące na różnice między małżonkami o wysokim i niskim poziomie transgresji, skupione wokół jednego z pięciu psychonów - motywacyjnego, który jest elementem sieciowej teorii osobowości, zachęcają do dalszych poszukiwań w tym kierunku. W przypadku prezentowanych badań skupiono się na analizie wyników żon i mężów z różnych związków małżeńskich. Warto byłoby w przyszłości zrealizować większy projekt badawczy, biorący pod uwagę analizę wyników na poziomie par małżeńskich o różnym rozkładzie poziomu transgresji: 1) oboje małżonków o wysokim poziomie transgresji; 2) oboje małżonków o niskim poziomie transgresji; 3) żona o wysokim, a mąż o niskim poziomie transgresji; 4) mąż o wysokim, a żona o niskim poziomie transgresji. Przeprowadzenie takiego projektu badawczego dostarczyłoby danych pozwalających na bardziej wnikliwe ujęcie mechanizmów psychologicznych funkcjonowania współczesnych związków małżeńskich w aspekcie motywacyjnym.

\section{BIBLIOGRAFIA}

Alderfer, C. (1992). Existence, relatedness and growth. New York: The Free Press. Baniak, J. (2004). Znaczenie dialogu w małżeństwie. Małżeństwo i Rodzina, 1, 25-28. Biernat, T., Sobierajski, P. (2007). Młodzież wobec małżeństwa i rodziny. Raport z badań. Toruń: Wydawnictwo Uniwersytetu Mikołaja Kopernika.

Cloud, H., Townsend, J. (2007). Granice w relacjach matżeńskich. Warszawa: Oficyna Wydawnicza „Vocatio”. 
Dakowicz, A. (2011). Potrzeby indywidualne małżonków zadowolonych i niezadowolonych ze swojego związku. Edukacja. Studia, badania, innowacje, 3, 99-105.

Dakowicz, A. (2012). Psychologiczna analiza małżonków o wysokim i niskim poziomie transgresji. W: T. Rostowska, A. Lewandowska-Walter (red.), Mał̇̇eństwo i rodzicielstwo a zdrowie (s. 79-101). Toruń: Wydawnictwo Adam Marszałek.

Dakowicz, A. (2014). Powodzenie małżeństwa. Uwarunkowania psychologiczne w perspektywie transgresyjnego modelu Józefa Kozieleckiego. Białystok: Wydawnictwo Uniwersyteckie Trans Humana.

Dyczewski, L. (2007). Małżeństwo i rodzina upragnionymi wartościami młodego pokolenia. W: L. Dyczewski (red.), Małżeństwo i rodzina w nowoczesnym społeczeństwie (s. 11-34). Lublin: Wydawnictwo Katolickiego Uniwersytetu Lubelskiego.

Fromm, E. (1999). Mieć czy być? Poznań: Dom Wydawniczy REBIS.

Gizicka, D. (2008). Kohabitacja - droga do małżeństwa czy jego alternatywa? W: W. Muszyński, E. Sikora (red.), Miłość, wierność i uczciwość na rozstajach współczesności. Kształty rodziny współczesnej (s. 416-426). Toruń: Wydawnictwo Adam Marszałek.

Gorbatkow, A. (2008). Pozytywno-negatywna asymetria emocji a rozwój podmiotowy jednostki. W: I. Pufal-Struzik (red.), O przekraczaniu granic własnych ograniczeń - z perspektywy psychotransgresjonizmu (s. 97-112). Kraków: Oficyna Wydawnicza „Impuls”.

Gottman, J. M. (2014). What predicts divorce? The relationship between marital processes and marital outcomes. New York: Psychology Press.

Górniak, J., Wachnicki, J. (2003). Pierwsze kroki w analizie danych SPSS PL for Windows. Kraków: SPSS Polska.

Hall, C. S., Lindzey, G. (1990). Teorie osobowości. Warszawa: Państwowe Wydawnictwo Naukowe.

Horney, K. (1993). Nerwica a rozwój człowieka. Trudna droga do samorealizacji. Poznań: Dom Wydawniczy REBIS.

Jabłoński, D., Ostasz, L. (2001). Zarys wiedzy o rodzinie, małżeństwie, kohabitacji i konkubinacie. Perspektywa antropologii kulturowej i ogólnej. Olsztyn: Wydawnictwo Adiaphora.

Janicka, I. (2004). Poczucie osamotnienia w małżeństwie. Psychologia Rozwojowa, 9(2), $55-63$.

Janicka, I. (2010). Jakość małżeństw poprzedzonych kohabitacją. W: T. Rostowska, A. Peplińska (red.), Psychospołeczne aspekty życia rodzinnego (s. 94-109). Warszawa: Difin.

Kornaszewska-Polak, M. (2013). Psychologiczne uwarunkowania komunikacji między małżonkami a różnice płci. Kwartalnik Naukowy Fides et Ratio, 3(15), 70-84.

Kowerski, M., Kowal, M. (2014). Marital separation in Poland. Regional aproach. Barometr Regionalny, 12(1), 123-132.

Kozielecki, J. (2006). Reforma polskiej gospodarki: studium decyzji transgresyjnych. W: E. Aranowska, M. Goszczyńska (red.), Człowiek wobec wyzwań i dylematów współczesności (s. 17-43). Warszawa: Wydawnictwo Naukowe SCHOLAR.

Kozielecki, J. (2007). Psychotransgresjonizm. Nowy kierunek psychologii. Warszawa: Wydawnictwo Akademickie „Żak”.

Kwarciak, K. (2003). Psychologiczne wyznaczniki skutecznego przedsiębiorcy. Acta Universitatis Wratislawiensis. Prace Psychologiczne, 6, 145-154. 
Lachowska, B. (2012). Praca i rodzina. Konflikt czy synergia? Konflikt i facylitacja między rolami rodzinnymi i zawodowymi - uwarunkowania i znaczenie dla jakości życia kobiet i mężczyzn. Lublin: Wydawnictwo Katolickiego Uniwersytetu Lubelskiego.

Ledzińska, M. (2006). Globalizacja i transgresja. W: E. Aranowska, M. Goszczyńska (red.), Człowiek wobec wyzwań i dylematów współczesności (s. 172-188). Warszawa: Wydawnictwo Naukowe SCHOLAR.

Łukowska, K. (2011). Posiadać więcej, ale czuć się gorzej - konsumpcyjny model współczesnej rodziny. W: H. Liberska, A. Malina (red.), Wybrane problemy współczesnych małżeństw i rodzin (s. 191-201). Warszawa: Difin.

MacKenzie, M. J., Baumeister, R. F. (2014). Meaning in life: nature, needs, and myths. W: A. Batthyany, P. Russo-Netzer (red.), Meaning in positive and existential psychology (s. 25-37). New York: Springer Science and Business Media.

Maslow, A. H. (1990). Motywacja i osobowość. Warszawa: Instytut Wydawniczy PAX.

Miner, M., Dowson, M., Malone, K. (2013). Spiritual satisfaction of basic psychological Needs and Psychological Health. Journal of Psychology and Theology, 41, 298-314.

Obuchowski, K. (1995). Przez galaktykę potrzeb. Psychologia dążeń ludzkich. Poznań: Dom Wydawniczy REBIS.

Perrone-McGovern, K. M., Oliveira-Silva, P., Simon-Dack, S., Lefdahl-Davis, E., Adams, D., McConnell, J., Howell, D. Hess, R. Davis, A., Gonçalves, Ó. F. (2014). Effects of empathy and conflict resolution strategies on psychophysiological arousal and satisfaction in romantic relationships. Applied Psychophysiology and Biofeedback, 39, 19-25.

Plopa, M. (2010). Małżeństwo w percepcji młodych Polaków. W: T. Rostowska, A. Peplińska (red.), Psychospołeczne aspekty życia rodzinnego (s. 64-93). Warszawa: Difin.

Popek, S., Bernacka, R. E. (2008). Zdolności i uzdolnienia - ujęcie transgresyjne. W: I. Pufal-Struzik (red.), O przekraczaniu granic własnych ograniczeń - z perspektywy psychotransgresjonizmu (s. 13-21). Kraków: Oficyna Wydawnicza „Impuls“.

Prasad, G. (2006). The great Indian family: New roles - old responsibilities. New Delhi: Penguin Books.

Reddin, B. (1993). Testy dla menedżerów stawiających na efektywność. Warszawa: Oficyna Wydawnicza „Alma-Press”.

Rostowski, J. (2009). Współczesne przemiany rozumienia związku małżeńskiego. W: T. Rostowska (red.), Psychologia rodziny. Małżeństwo i rodzina wobec współczesnych wyzwań (s. 15-46). Warszawa: Difin.

Rostowski, J., Rostowska, T. (2014). Małżeństwo i miłość. Kontekst psychologiczny i neuropsychologiczny. Warszawa: Difin.

Sitarczyk, M., Waniewski, A. (2002). Empatia a zadowolenie z małżeństwa. Małżeństwo i Rodzina, 3, 28-32.

Slotter, E. B., Duffy, C. W., Gardner, W. L. (2014). Balancing the need to be "me" with the need to be "we": Applying Optimal Distinctiveness Theory to the understanding of multiple motives within romantic relationships. Journal of Experimental Social Psychology, 52, 71-81.

Stępniak-Łuczywek, A. (1997). Uwarunkowania szczęścia małżeńskiego. Problemy Rodziny, $5-6,13-20$. 
Strzałecki, A. (2006). Transgresja polskich menedżerów w warunkach transformacji ustrojowej. W: E. Aranowska, M. Goszczyńska (red.), Człowiek wobec wyzwań i dylematów współczesności (s. 108-132). Warszawa: Wydawnictwo Naukowe SCHOLAR.

Studenski, R. (2006). Skłonność do ryzyka a zachowania transgresyjne. W: M. Goszczyńska, R. Studenski (red.), Psychologia zachowań ryzykownych. Koncepcje, badania, praktyka (s. 128-142). Warszawa: Wydawnictwo Akademickie „Żak”.

Ślaski, S. (2012). Motywacyjno-osobowościowe wyznaczniki zachowań transgresyjnych i ochronnych. Warszawa: Wydawnictwo Uniwersytetu Kardynała Stefana Wyszyńskiego.

Ślaski, S. (2013). Transgresja a psychoterapia mężczyzn uzależnionych od alkoholu. Psychoterapia, 2, 83-98.

Tański, M. (2005). Kontrowersje wokół koncepcji transgresyjnej Józefa Kozieleckiego. Studia Humanistyczne, 3, 137-143.

Tokarz, A. (2005). Dynamika procesu twórczego. Kraków: Wydawnictwo Uniwersytetu Jagiellońskiego.

Żemojtel-Piotrowska, M., Piotrowski, J., Baran, T. (2014). Roszczeniowość a satysfakcja ze związku intymnego, Studia Psychologiczne, 52(1), 21-32. 